\title{
O feminino em mídias digitais: usos de imagens e redes sociais na construção de referências emocionais de gênero
}

\author{
Túlio Cunha Rossi \\ Professor Doutor da Universidade Federal Fluminense - UFF \\ tuliorossi@gmail.com
}

\begin{abstract}
Resumo Este artigo discute como imagens da feminilidade hoje são socialmente constituídas, compartilhadas e reproduzidas em redes sociais e mídias digitais, tanto pelas próprias usuárias quanto em campanhas publicitárias direcionadas ao público jovem feminino. O artigo consiste na análise de dez vídeos publicitários compartilhados em redes sociais e disponíveis no canal de vídeos Youtube, combinada à análise do conteúdo de entrevistas semiestruturadas, realizadas com dez mulheres com idade entre 18 e 25 anos e usuárias da rede social Facebook. Observou-se a manutenção de crenças e valores referentes à vida íntima e afetiva, no que persistem, ainda que ressignificados, ideais heteronormativos e monogâmicos de união afetiva, nos quais o casamento e a maternidade seguem como elementos significativos na constituição de projetos de vida femininos. Nisso, persistiria, sob novos mecanismos de reprodução e interpretação, uma idealização romântica de relacionamentos amorosos e de uma "natureza feminina” marcada pela inclinação à afetividade.
\end{abstract}

Palavras-chave: gênero; feminilidade; mídias digitais; imagens; sociologia das emoções.

\section{Introdução}

$\mathrm{O}$ presente artigo discute os resultados da pesquisa Amor e sexualidade em construção: consumo, internet e mídias audiovisuais na socialização afetivo-sexual feminina, ${ }^{1}$ na qual se buscou compreender como imagens da feminilidade são socialmente constituídas hoje, com ênfase em noções de afetividade e emoções como características naturalizadas como "femininas". Nesse sentido, discorre-se sobre imagens e discursos que caracterizam o feminino pela afetividade, difundidos em mídias audiovisuais e digitais.

A pesquisa partiu de questionamentos especificamente direcionados a processos de socialização afetivo-sexual feminina, no presente contexto de usos de mídias digitais e redes sociais. Para tanto, a investigação foi dividida em dois momentos, começando pela análise de vídeos publicitários compartilhados em redes sociais e disponíveis no canal de vídeos Youtube, divulgados entre 2011 e 2015, direcionados prioritariamente ao público feminino e tematizando, de alguma for-

1. Pesquisa realizada de janeiro de 2015 a dezembro de 2016, com o apoio institucional do Departamento de Sociologia e Antropologia da Universidade Federal do Maranhão (DESOC-UFMA). 
ma, relacionamentos afetivo-sexuais - casamentos, namoros, busca por parceiros afetivos.

No segundo momento, foram realizadas dez entrevistas semiestruturadas com jovens usuárias de redes sociais virtuais, com idade entre 18 e 25 anos, habitantes da cidade de São Luís, capital do Maranhão. Levando em consideração que o uso de mídias digitais vem tomando proporções significativas no que diz respeito à circulação de informações e discursos na atualidade, priorizou-se uma análise específica não só do uso, mas da importância dessas mídias para a manutenção e desenvolvimento das relações afetivas e prescrições emocionais sob a perspectiva de jovens mulheres.

As análises dos vídeos publicitários, combinadas à análise do conteúdo das entrevistas, permitiram observar um discurso ainda muito presente que associa, de forma naturalizada, feminilidade, cuidados estéticos com o corpo e sucesso na vida afetiva. Notou-se que, mesmo em vídeos e discursos que aparentam desconstruir ou questionar esses estereótipos de feminilidade, persiste a ideia de relacionar a autoestima feminina a seu valor estético e à conquista ou manutenção de um relacionamento afetivo (heterossexual e monogâmico).

Foram investigados discursos - tanto em depoimentos quanto em vídeos analisados - com proposições mais ou menos explícitas de "certo" e "errado", direitos e deveres, padrões e desvios, o que esperar e o que buscar em um relacionamento afetivo. Para isso, adotou-se o conceito de "normas emocionais":

Normas emocionais indicam a extensão, a intensidade, a duração e/ou os propósitos de emoções específicas em dadas situações. Normas que, em geral, são indicadas por afirmações contendo termos como "deveria", "precisa", ou "tem direito a" em referência a sentimentos ou quadros de sentimentos. (Thoits, 1991, p. 181).

Por conseguinte, este artigo sublinha o direcionamento específico de alguns preceitos, modos de agir e de sentir tipificados como "femininos", constituindo um processo socializador altamente diferenciado e reiterado em mídias audiovisuais e digitais. No âmbito específico da afetividade, nota-se como central a construção de parâmetros de diferenciação sexual pautados por noções heteronormatizadas de divisões de papéis complementares entre gêneros binários que, frequentemente, são celebrados perante a sociedade pela instituição do matrimônio.

Levando em conta aspectos históricos e geracionais, relacionados tanto a percepções de gêneros e afetividade quanto às relações com novas mídias, também se discute como redes sociais virtuais - especialmente o Facebook - participam da socialização de jovens brasileiras e de eventuais direcionamentos de cursos de vidas em relação ao amor, dentre outras maneiras, pelo recurso a imagens fotográficas, vídeos e textos. Nesse sentido, foram enfatizados os aspectos de comunicação, a partir de dispositivos de mídias digitais, na propagação de discursos que tematizassem diretamente o aspecto da afetividade e da constituição de relacionamentos amorosos como interesses distintamente "femininos".

\section{Gêneros, sexualidades, afetividades}

Embora pareça ponto pacífico a preferência pela utilização da categoria "gênero" - que, conceitualmente, distancia-se da categoria "sexo" ao recusar sua naturalização e realçar seu caráter sociocultural e histórico -, os entendimentos sobre gênero ainda são objeto de intensos debates. Seu cerne se situaria não no reconhecimento dos aspectos culturais de diferenciação e hierarquização social fundamentados no gênero, mas, principalmente, na tentativa de identificar os limites entre o que é "gênero" (enquanto algo culturalmente determinado) e o que é "sexo" (algo natural, universal e anterior à cultura), buscando diferenças essenciais.

Há, ainda, a problematização da própria noção de sexo como algo também constituído social e historicamente, a partir do gênero. Como afirma Verena Stolke (2004, p. 93): "No lugar de indagar sobre a relação entre sexo e gênero, haveria que se perguntar sobre as circunstâncias históricas em que o dualismo sexual biológico e a sexualidade podem ter consequências sócio-políticas e de gênero".

Assim, o dualismo sexual se torna objeto de dispositivos disciplinadores da reprodução social quando ideologias baseadas na distinção biológica sustentam uma ordem sociopolítica desigual. Destarte, partiu-se da categoria analítica "gênero" justamente no sentido de ressaltar seus aspectos culturais, sociais e históricos, os quais, por sua vez, entende-se, interferem na própria vivência performativa das noções naturalizadas de sexo, influenciando modos de pensar, agir, sentir e desejar.

Joan Scott (1990, p. 86) define gênero a partir de duas proposições: "(1) o gênero é um elemento constitutivo de relações sociais baseadas nas diferenças percebidas entre os sexos e (2) o gênero é uma forma primária de dar significado a relações de poder". Convém sublinhar que a autora se refere a diferenças percebidas entre os sexos, de certo modo escapando da essencialização pautada por discursos de determinismo biológico. 
É importante observar, também, que a autora traz à tona o debate sobre as interseccionalidades e as complexas combinações existentes em formas reconhecidamente diferentes de significação de relações de poder, envolvendo outras variáveis como classe e raça. Estes entrecruzamentos, frequentemente, contrapõem-se a diferentes posicionamentos teóricos que buscam um determinante essencial para todas as formas de desigualdades, atribuindo às demais um caráter secundário.

Sob outra perspectiva, Judith Butler (2013, p. 25) questiona mais incisivamente a ideia de gênero como significação cultural de diferenças essenciais entre os sexos, a qual partiria da perspectiva de existência de um sexo - masculino ou feminino - anterior à cultura e, portanto, "natural":

Se o sexo é, ele próprio, uma categoria tomada em seu gênero, não faz sentido definir o gênero como a interpretação cultural do sexo. $O$ gênero não deve ser meramente concebido como a inscrição cultural de significado num sexo previamente dado (...); tem de designar também o aparato mesmo de produção mediante o qual os próprios sexos são estabelecidos. Resulta daí que o gênero não está para a cultura como o sexo para a natureza; ele também é o meio discursivo/cultural pelo qual "a natureza sexuada" ou "um sexo natural" é produzido e estabelecido como "pré-discursivo", anterior à cultura, uma superfície politicamente neutra sobre a qual age a cultura.

A problematização do desejo sexual como norma naturalizada contribui para os debates de gênero, quando a ilusão de coerência e continuidade é colocada à prova e se percebe que ela é constantemente reiterada por discursos e práticas em diferentes esferas, da jurídica à íntima e afetiva. Nesse aspecto, embora não tematizada nesse texto da autora, uma afetividade "legítima" também é construída sobre os pressupostos do sistema de continuidade e coerência entre sexo, gênero e desejo. Alguns desejos, posturas e gestos são significados como mais apropriados do que outros, por vezes censurados e silenciados.

Práticas coerentes - no que se incluem até mesmo formas de sentir - são estimuladas conforme gêneros atribuídos desde o nascimento. Partindo da perspectiva de que os corpos são disciplinados (Foucault, 2009), pode-se interpretar que a significação dos sentimentos e prazeres também opera conforme regimes disciplinares. Alguns, como é o caso do amor romântico heterossexualizado e monogâmico, são considerados "nobres" - sendo, portanto, incentivados - e outros, "abomináveis", como são referidos os demais comportamentos que fogem a essa matriz.

Indivíduos aprendem não somente a agir, apresentar-se e reconhecer-se conforme gêneros atribuí- dos; esse processo se dá também de forma ativa, mais ou menos consciente e intencional, envolvendo práticas e discursos que reiteram - para si e para os outros noções de identidades coerentes. Destarte, outra contribuição fundamental de Butler (2000, p. 121) para este debate é a noção de performatividade:

A performatividade não é, assim, um "ato" singular, pois ela é sempre uma reiteração de uma norma ou conjunto de normas. E na medida em que ela adquire o status de ato no presente, ela oculta ou dissimula as convenções das quais ela é uma repetição. Além disso, esse ato não é primariamente teatral; de fato, sua aparente teatralidade é produzida na medida em que sua historicidade permanece dissimulada.

Percebe-se, assim, uma indissociável relação entre uma abordagem sociológica de gênero e socialização enquanto internalização e reprodução de normas, sendo estas percebidas como contínuas e não limitadas às instituições família e escola.

Isso estimula várias questões: como e por quais meios suas práticas são aprendidas, especialmente as que dizem respeito à subjetividade, às emoções e à intimidade? Como estes aprendizados se legitimam e se estendem para um sem número de indivíduos que os reconhecem, reproduzem e, eventualmente, ensinam, ao mesmo tempo que acreditam "viver naturalmente", em coerência com seus desejos e sua individualidade? As respostas, longe de se limitar a uma causa única, contemplam múltiplas instâncias da vida social, como a política, a jurídica e a religiosa; principalmente, envolvem o campo das ações e interações consideradas mais pessoais e espontâneas.

O aspecto das normas emocionais (Thoits, 1991) revela sua importância, uma vez que estas estabelecem modos específicos de agir, sentir e, no caso de relações amorosas, fomentar expectativas em relação a sua conquista e preservação. De tal forma que não são apenas as opiniões e os discursos morais declarados sobre o sexo que determinariam ações em relação à sexualidade, mas, principalmente, questões sobre como, quando e por quem determinados sentimentos - não limitados às pulsões sexuais - são legítimos ou não. Nesse sentido, concorda-se aqui com Eva Illouz (2011, p. 10):

É banal dizer que a divisão e a distinção mais fundamentais que organizam quase todas as sociedades do mundo - a divisão e a distinção que existem entre homens e mulheres - baseiam-se nas culturas afetivas (e se reproduzem através delas). Ser um homem de caráter exige que o indivíduo demonstre coragem, racionalidade fria e agressividade disciplinada. A feminilidade, por outro lado, requer bondade, compaixão e otimismo. A hierarquia social produzida pelas 
divisões de gênero contém divisões afetivas implícitas, sem as quais homens e mulheres não reproduziriam seus papéis e identidades.

Portanto, urge reconsiderar, de forma ainda mais cautelosa e aprofundada, não somente os discursos utilizados para diferenciar - hierarquicamente - "feminilidades" de "masculinidades", mas, especialmente, as perspectivas constituídas em torno das emoções que são mobilizadas no sentido de reiterar essas diferenciações como "naturais" e dentro de uma escala valorativa que reproduz, pela via dos afetos, relações de desigualdade e dominação.

No caso de jovens socializadas de modo a sobrevalorizar o aspecto afetivo em relação ao sexual, pressupondo uma polarização moral entre um e outro, isso é mais evidente enquanto interpretação e significação das próprias emoções e, talvez, até mesmo da libido. Isso contribui para a construção de identidades femininas, bem como para a própria constituição de relações sociais específicas entre gêneros, pautadas por formas específicas de experimentar as emoções, bem como de interpretá-las interativamente. Conforme Stephanie Shields (2002, p.14):

ideias sobre emoções estabelecem fronteiras de gênero: crenças sobre emoções são usadas para "distinguir” os rapazes das garotas. Quais são as implicações práticas, pessoais e sociais dessa proposição? À medida que crenças emocionais criam e mantêm fronteiras de gênero, elas estão, no sentido mais profundo, implicadas na criação de nossas identidades como mulheres e homens. Ao fazer emoções do jeito "certo", reivindica-se autenticidade como uma pessoa. Mas quem define o modo certo de se fazer emoções?

Persiste no senso comum uma significação da sexualidade e do prazer femininos que os condiciona ao ideal amoroso para se legitimar, sendo este muitas vezes percebido como forçosamente atrelado à contração do matrimônio. A isso, somam-se discrições culturalmente difundidas que opõem "razão" e "emoção", com tendência a tratar a última como expressão autêntica da natureza humana e reforçando a ideia de inclinação feminina à afetividade como caráter biologicamente determinado de preservação da prole, reafirmando-se por meio da maternidade.

\section{Feminilidade em imagens: a publicidade em mídias digitais}

Existem configurações e situações sociais específicas que balizam a expressão das emoções e entende-se, ao mesmo tempo, que também contribuem para as formas como estas são experimentadas e interpretadas pelos atores. Como exemplo, discursos socializadores ainda persistentes em relação ao choro, direcionados a meninos, definem não apenas socialmente, mas também psicologicamente, formas de significar, valorizar e vivenciar sentimentos de frustração, tristeza e dor, potencialmente maiores ou menores conforme a capacidade e os limites de autocontrole de cada indivíduo.

Mais que restringir a socialização a determinada fase da vida, situada da infância até o limiar da idade adulta, é importante ter em mente seu aspecto contínuo, não apenas na qualidade de aprendizado, mas como forma de ativar e reativar determinados aprendizados; de colocá-los em prática e reiterá-los cotidianamente, bem como de agir conforme esses aprendizados, acreditando no próprio comportamento expressivo como reflexo mais direto e espontâneo de si. Afinal, assegura Goffman (1987, p. 7): "Somos socializados para confirmar nossas próprias hipóteses sobre nossas naturezas".

Assim, considera-se que a atual oferta de referências simbólicas e comportamentais propiciada por mídias digitais tem relevante papel em processos socializadores, tanto na manutenção quanto na transformação da significação e percepção de elementos diferenciadores de gêneros, podendo, às vezes, reforçar a crença em sua naturalidade por via de construção de imagens e narrativas que reiterariam essa "naturalidade". Entendendo que na socialização estão implicadas formas de ver o mundo e experimentar a "realidade", o contexto atual de penetração da internet no cotidiano via redes sociais e comunidades virtuais permite desdobramentos nos quais as imagens são parte importante da experiência. Concorda-se com Scott McQuire (2008, p. 203), quando este afirma que

as mídias modernas não são simplesmente formas de "representação", no sentido de prover imagens que reflitam ou distorçam uma realidade social já estabelecida em qualquer lugar. Antes, sugeri que as novas plataformas de mídia têm consistentemente contribuído para a formação de novos modos de percepção e conhecimento, bem como para a produção de novas formas e locais de ação social. [...] Mídias não mais pertencem primariamente a locais especializados espacialmente delimitados tais como o cinema, mas estão se tornando móveis e penetrantes. Mais 
do que registro de eventos passados, mídias digitais frequentemente oferecem feedback instantâneo em “tempo real”. Não somente as interações sociais rotineiramente distribuídas através de matrizes heterogêneas de tempo-espaço, mas a mediação por sistemas tecnológicos complexos tornou-se integral para a dinâmica social.

O que é corroborado por Castells (2005, p. 459, grifo do autor):

O que é um sistema de comunicação que, ao contrário da experiência histórica anterior, gera virtualidade real? É um sistema em que a própria realidade (ou seja, a experiência simbólica/material das pessoas) é inteiramente captada, totalmente imersa em uma composição de imagens virtuais no mundo do faz-de-conta, no qual as aparências não apenas se encontram na tela comunicadora da experiência, mas se transformam na experiência. Todas as mensagens de todos os tipos são incluídas no meio porque este fica tão abrangente, tão diversificado, tão maleável, que absorve no mesmo texto de multimídia toda a experiência humana, passado, presente e futuro [...].

Se, por um lado, a incorporação das novas tecnologias tem sido crescente na vida cotidiana, por outro, parece haver pouca problematização sociológica da presença dessas novas tecnologias, principalmente para gerações já socializadas na presença delas desde a infância. Há que se considerar um importante aspecto geracional aqui, o qual contribui para a percepção da relevância sociológica do estudo de novas mídias:

O uso da rede é muito maior entre aqueles que nasceram ou chegaram à adolescência em meio à sua expansão comercial no final da década de 1990, portanto tendo mais chance e interesse de acionar seu uso para manter e/ou expandir suas relações sociais. Pessoas nascidas antes da década de 1970 já eram adultos com mais de 25 anos em 1997, portanto já haviam sido educados, socializados e constituído boa parte de seus vínculos sociais por outros meios. Não é de se estranhar que, para elas, a internet surgiu apenas como uma possibilidade extra de comunicação e foi incorporada de forma mais lenta e menos central em suas vidas. (Miskolci, 2011, p. 11).

Adotou-se aqui, então, uma perspectiva compreensiva para investigar as construções de sentidos relacionados à vida afetiva e sexual feminina e o modo como esses sentidos incidem na orientação de ações e interações, principalmente para gerações mais jovens e habituadas ao uso cotidiano das mídias digitais. Buscaram-se aspectos de significação recorrentes nas campanhas analisadas, no que se refere às conexões entre feminilidade e afetividade. Conforme Weber (2008, p. 29):

Procuramos compreender a realidade da vida que nos rodeia e na qual nos encontramos situados naquilo que tem de específico; por um lado, as conexões e a significação cultural de suas diversas manifestações na sua configuração atual e, por outro, as causas pelas quais se desenvolveu assim, e não de outro modo.

Entende-se que as gerações mais jovens, chamadas de "nativos digitais" (Prensky, 2001), detêm como característica específica o contato rotinizado com mídias digitais e redes sociais virtuais incorporadas às suas interações cotidianas, os relacionamentos afetivos incluídos. Tendo em vista as especificidades tanto do aspecto de gênero quanto do geracional, levou-se em conta, rigorosamente, o que afirma Richard Miskolci (2011, p.10):

Alguém interessado em explorar o estudo de mídias digitais precisa estar atento para o fato de que elas potencializam e transformam meios anteriores de comunicação, os quais, por sua vez, já foram inovadores e causaram grandes mudanças sociais e subjetivas. Um bom exemplo é o de como as mensagens instantâneas atuais foram precedidas pelo serviço postal, em especial, o telegrama, o qual já foi a forma avançada e rápida da troca de correspondência.

A seleção dos vídeos levou em conta, principalmente, campanhas publicitárias que geraram polêmicas e reações diversas nas redes sociais, envolvendo questões ligadas à feminilidade no contexto de relacionamentos íntimos. Foram analisados os seguintes vídeos: \#JuntasContraVazamentos (Always Brasil, 2015); Histórias reais do primeiro encontro (Samsung Brasil, 2014); Homenagem surpresa no cinema (Natura Brasil, 2011); O Boticário - Homenagem Dia dos Namorados (O Boticário, 2014); Toda mulher merece um elogio (Villa, Scala, Carmen Steffens - São Luís, MA, 2013); No te mueras por mi (ONG Vida Mujer - Peru, 2015); Avon MegaPraCima (Avon, 2015); Primavera-Verão Moda intima (Marisa, 2012); Fernanda Lima apresenta: Activia. Você bem por dentro e por fora (Danone Brasil, 2015); Nativa SPA - A fila anda (O Boticário, 2012).

Os procedimentos de análise se basearam na sociologia do cinema de Pierre Sorlin (1982), cuja ênfase está na análise do produto fílmico como construção, encadeando diferentes planos, sequências e recursos técnicos como som, luz e trilha sonora para "contar uma história”. Esse método também propõe o reconhecimento dos realizadores da produção como inseridos em um contexto social e histórico, guiando 
seus olhares conforme esse contexto, selecionando e extraindo elementos percebidos como "familiares".

Também faz parte da metodologia de Pierre Sorlin (1982, p. 230) a identificação de "pontos de fixação", que indicam, dentro de uma determinada amostra de filmes do período analisado, "um problema ou um fenômeno que, sem ser diretamente implicado na ficção, aparece regularmente [...] e é sinalizado por alusões, repetições, uma insistência particular da imagem ou de um efeito de construção". O ponto de fixação presente na maioria dos vídeos e que chamou mais atenção aqui foi o apelo à "realidade", a partir de subterfúgios como registrar cenas "reais" com câmeras escondidas, apresentar depoimentos estruturados de forma análoga a documentários ou, até mesmo, utilizar vídeos e materiais produzidos e disponibilizados pelos próprios usuários das redes sociais.

Mais que buscar comparar as imagens analisadas com uma suposta "realidade", problematizou-se a própria construção social dos olhares que atribuem a essas imagens características de "verdade", "realismo" e atratividade, entre outras. A esse respeito, embora referindo-se especificamente à fotografia, José de Souza Martins (2008, p. 28) adverte:

A fotografia é muito mais indício do irreal do que do real, muito mais o supostamente real recoberto e decodificado pelo fantasioso, pelos produtos do autoengano necessário e próprio da reprodução das relações sociais e do seu respectivo imaginário. A fotografia, no que supostamente revela e no seu caráter indicial, revela também o ausente, dá-lhe visibilidade, propõe-se antes de tudo como realismo da incerteza.

Notou-se uma relação profundamente diferenciada com o uso de vídeos no contexto das mídias digitais e redes sociais, tanto do lado das empresas e organizações que os produzem, quanto do lado das usuárias que, eventualmente, os recebem, comentam e compartilham. Isso tem demandado esforços do ponto de vista metodológico, ao se reconhecer limitações dos métodos de análise de produções audiovisuais aqui empregados, originalmente pensados para a mídia cinematográfica. Contudo, a análise do conteúdo das imagens e das estratégias de construção narrativa dos vídeos reforçou a impressão de como, mesmo em outras mídias, esses vídeos estão impregnados de elementos, técnicas e signos que remetem à indústria cinematográfica.

A própria ideia de uma das campanhas promover uma "homenagem surpresa" (Natura Brasil, 2011) justamente em uma sala de cinema, com a projeção na grande tela de um vídeo gravado com webcam e enviado por e-mail para a empresa responsável pela campanha, é simbólico de como essas mídias se in- terpenetram. A isso relacionam-se questões sobre o reiterado apelo emocional atribuído às imagens - cinematográficas, televisivas, publicitárias e, atualmente, produzidas pelos próprios usuários de redes sociais com aplicativos como Instagram -, reiterando máximas do senso comum como "uma imagem vale mais do que mil palavras".

Um aspecto recorrente entre os vídeos analisados foi a promoção da participação de usuários - seja dos produtos anunciados ou das redes sociais -, com campanhas às vezes propagando vídeos gravados por usuários ou contando com depoimentos, homenagens e até "surpresas" com câmeras escondidas, no que pareceu ensejar-se a aproximação com "pessoas comuns", conferindo aspectos de "realismo" às campanhas. Em relação à publicidade que busca um contato com a "realidade" do potencial consumidor, Beleli (2007, p. 194) observa:

Nessa mediação, a evocação da "experiência", como sinônimo de autenticidade, é uma importante estratégia publicitária para despertar a atenção do consumidor, propondo identificações entre as vidas cotidianas e aquilo que as marcas/produtos oferecem. Nesse sentido, uma propaganda eficaz é aquela que oferece a 'sensação' de que o consumidor está escolhendo livremente um modo de ser.

Nessas aproximações com uma suposta "realidade", por vezes se notava mais a reiteração do que o questionamento de alguns estereótipos de gênero e de formas de expressão da afetividade, no que as "declarações de afeto" partindo dos homens geralmente tinham em vista algum aspecto estético das suas mulheres: um elogio ao cabelo (Natura Brasil, 2011), a lembrança da roupa utilizada no primeiro encontro (Samsung Brasil, 2014) ou a admiração após a transformação da aparência da parceira com novas roupas, acessórios, maquiagem e penteado (Villa, Scala, Carmen Steffens - São Luís, MA, 2013).

É curioso observar como, nessas campanhas, o distanciamento entre "imagem" e "realidade", embora muito presente no senso comum, revela-se cada vez mais dúbio, notando-se, reiteradamente, a incorporação e as interpenetrações entre imagem e realidade - em relações que se tornam praticamente indistintas, mas, antes, complementares -, reproduzindo, tanto em imagens quanto em experiências cotidianas, padrões heteronormativos de relacionamentos e estereótipos de feminilidade que a associam, de forma naturalizada, ao valor estético e às emoções.

Todavia, é importante considerar que as "histórias reais" aqui referidas são também uma espécie de mise-en-scène social, encenada por seus participantes, assim como os filmes. Nesse aspecto, elas constituem 
primeiramente uma seleção (certos objetos e não outros) e depois uma redistribuição. Ele reorganiza, com elementos tomados, essencialmente, dentro do universo ambiente, um conjunto social que, em certos aspectos, evoca o meio de onde ele é içado, mas, essencialmente, é uma retradução imaginária (Sorlin, 1982, p. 200).

Os comerciais analisados, em sua maioria, não ressaltaram de imediato a emotividade das mulheres, mas condicionaram sua felicidade e satisfação a relacionamentos afetivos com homens, até mesmo justificando a aquisição dos produtos, como no caso de campanhas como a de Primavera-verão moda íntima (Marisa, 2012).

Essa campanha utilizava o argumento de que "no Brasil, existem apenas 96 mulheres para cada 100 homens", reduzindo, a cada plano, o número de homens "disponíveis", com base em várias razões, muitas delas ligadas a estereótipos de homossexualidade masculina, ("12 não gostam do assunto", "1 tem um poodle", "5 fazem a unha" e "8 têm medo de barata"), além de informações como o fato de ser casados ou apresentar pouco interesse por sexo. Ao final, a campanha concluía que, para 96 mulheres, haveria apenas um homem interessante disponível, a ser disputado por todas elas, sugerindo que é "melhor caprichar" para vencer essa árdua disputa.

Considerando que se trata de um comercial de lingerie, que alterna imagens de modelos em trajes sensuais em quase todos os planos de seus 52 segundos, é patente que a estratégia sugerida pelo comercial para galgar tal vitória passa necessariamente pelo uso erotizado do corpo feminino como instrumento de sedução, com a finalidade primordial de conquistar um parceiro do sexo masculino livre de todos os "defeitos" que o comercial enumera.

O foco na aparência - ou no elogio a ela - também é central em outros comerciais aqui analisados, como o das lojas Villa, Scala e Carmen Steffens, em São Luís, no Maranhão. O comercial consistia em promover uma surpresa inusitada com câmeras escondidas: a partir do jargão popular de que homens não reparariam em mudanças na aparência de suas parceiras, a campanha promoveu um encontro, em um restaurante, entre casais selecionados, ocasião em que as mulheres se retiravam para ir ao toalete e recebiam um verdadeiro "tratamento de beleza", com roupas, acessórios e maquiagem das grifes que promoviam a campanha.

Após a "surpresa" e declarações "apaixonadas" dos parceiros, registradas pelas câmeras escondidas, havia um momento posterior, semelhante a uma entrevista com os parceiros, quando expressavam seu "amor" por suas mulheres. É sintomático, do ponto de vista de gênero, que essas declarações de amor sejam provocadas por um estímulo tão grotesco, o qual parece zombar da inteligência do espectador ao contestar que os homens não notariam mudanças tão radicais na aparência de suas parceiras, como as que o comercial promove.

Além disso, o comercial parece reiterar a ideia de que uma mulher só se mantém "digna de ser amada" conquanto cuide rigorosamente de sua aparência, no sentido de estimular o desejo sexual do seu parceiro ou de outros em potencial. Aqui há um encontro significativo com o que Anne Marie Bidaud (1994, p. 157) já assinalara, ao abordar a maneira como o cinema clássico americano constrói suas narrativas de amor:

Essa constante valorização do amor parece ser uma proposição ideológica na medida em que ela coloca em relevo modelos de comportamento bons para a ordem social e solidários ao consumo. O mercado da felicidade e o mercado da sedução são indissociáveis, uma vez que compramos suas armas (roupas, cosméticos, perfumes...).

Nada disso é surpresa em uma sociedade na qual a presença massiva de mídias de comunicação visual já se faz presente na vida cotidiana há décadas. O que se vê, neste e em outros comerciais com "imagens de pessoas reais", são performances de gênero e de afetividade espontaneamente incorporadas e naturalizadas, praticamente indistinguíveis daquelas estrategicamente construídas para o cinema, a televisão e a publicidade.

São formas com que a cultura do consumo e o imaginário romântico específico da heteronormatividade contemporânea se combinam de maneira produtiva: a reafirmação do amor, da feminilidade e da felicidade passa pelo aspecto simbólico do consumo de certos produtos ressignificado como "experiência pessoal". Isso é mais evidente no comercial Histórias reais do primeiro encontro, da linha de lavadoras de roupas da marca Samsung (2014): em um vídeo de pouco mais de cinco minutos, acompanham-se narrativas de três casais de diferentes gerações, encadeadas no sentido de desconstruir a premissa de que homens não atentariam a detalhes e datas, com dificuldade em lembrar elementos como o que suas parceiras vestiam em seu primeiro encontro.

Esse comercial também tem uma estrutura similar a documentário e propõe reconstruir, com uma espécie de surpresa, o primeiro encontro dos casais, quando as mulheres vestiriam uma roupa igual à que usaram naquela ocasião e (re)encontrariam seus parceiros no mesmo local. Ao final, o comercial constrói uma analogia relacionando a importância de preservar a memória e os momentos significativos de relacionamentos afetivos com a preservação das peças de roupas usadas no primeiro encontro, apresentando como dife- 
rencial de seu produto a qualidade de danificar menos as peças durante cada lavagem e permitir que tenham uma duração maior.

O vídeo é construído com narrativa, trilha sonora e ritmo que buscam promover reações de comoção e sublinhar o caráter "real" das histórias ali narradas, nas quais a peça de roupa - necessariamente feminina - adquire um valor simbólico e particular fundamental, ainda que não seja o produto anunciado. Assim, há todo um processo de significação e analogias sentimentais de objetos comercializáveis que não se restringem à narrativa fictícia criada pela propaganda, mas os próprios protagonistas das "histórias reais" tornam essa peça de roupa um significante de afeto e memória pessoal.

Outras campanhas também trabalharam a relação entre o valor estético da imagem da mulher e sua autoestima, não necessariamente condicionados à conquista de um relacionamento, mas, principalmente, como forma de superação de rompimentos e valorização de si. Este é o caso dos comerciais da linha de produtos Nativa SPA, A fila anda (O Boticário, 2012) e Mega pra cima (Avon, 2013). No primeiro, em aproximadamente trinta segundos, tem-se uma mulher que aceita um convite para jantar, banha-se e prepara-se (aparentemente de forma demorada) para o referido jantar com os produtos da linha anunciada.

O jantar acontece em um restaurante sofisticado e o homem que a acompanha diz: "Eu queria dizer que eu errei e quero voltar" (dando a entender que eles mantinham alguma espécie de relacionamento antes). Ela então responde, com um grande sorriso seguido de uma saída triunfal: "E eu queria te dizer que a fila anda". O comercial se encerra com a seguinte mensagem em voice-off: "Linha Nativa SPA O Boticário: você se sente".

Já o comercial da marca Avon é protagonizado por uma mulher em frente ao espelho, como quem está se arrumando para sair e conversando com seu reflexo: "É chato estar solteira. Pronto, falei". Em seguida, em tom de comédia, com atuação bastante histriônica, ela narra parte de seus descontentamentos por não estar mais em um relacionamento. No entanto, ao primeiro toque em seus cílios do rímel ${ }^{2}$ anunciado, como que magicamente sua percepção muda e ela começa a enumerar aspectos positivos de estar solteira e livre, encerrando o comercial efusivamente: "Eu amo ser solteira! Sabe por quê? Eu tô mega solteira, eu tô mega gostosa, eu tô mega bonita, eu tô mega tudo! Eu tô MEGAPRACIMA.”

Ao mesmo tempo que esses comerciais sugerem uma posição de empoderamento dessas mulheres, seja na recusa de um relacionamento com um homem ou ao reconhecer as benesses de "estar solteira", eles constroem o discurso de que essa superação, para as mulheres, precisa necessariamente passar pelo aspecto da aparência e da sensualidade. Há um estranho saldo aqui que parece reafirmar a construção da mulher tendo por chave seu valor estético e erótico, até mesmo para afirmar a sua aparente independência de um relacionamento afetivo.

Isso reitera não somente o peso demasiado depositado sobre os ombros femininos, em relação aos seus cuidados estéticos e à tentativa de adequação a padrões de beleza absurdos, como também a própria significância atribuída ao estar em um relacionamento afetivo e, nos casos construídos nesses comerciais, com um homem. A definição da autoestima das mulheres desses dois comerciais parece ainda constituída por seu status em relação a homens e/ou ao desejo masculino.

Goffman já sugerira, nos anos 1970, que uma das finalidades das imagens publicitárias é que os espectadores não precisem pensar a respeito para captar suas mensagens; por outro lado, as múltiplas dinâmicas de circulação de informações e opiniões das novas mídias têm, algumas vezes, não somente impelido os receptores a que "pensem" sobre essas imagens, como também que produzam suas próprias imagens, muitas vezes em conformidade com técnicas, estéticas e performances características do cinema, da televisão e da própria publicidade.

Há uma relação diferente com as imagens, no sentido de a internet oferecer ferramentas para que seus usuários expressem o que pensam em relação aos comerciais que assistem e, às vezes, a partir deles, até mesmo se mobilizem para diferentes causas. Isso se nota nas manifestações de internautas em redes sociais como Facebook e Twitter, comentando os comerciais e, dependendo do caso, promovendo reações públicas contra as marcas, ${ }^{3}$ bem como na produção de vídeos, em parceria com produtos, para fins de "conscientização" sobre determinados assuntos, como as campanhas \#Juntascontravazamentos (Always

2. O título da campanha, Mega pra cima, além de aludir ao efeito do produto, utilizado para realçar os cílios e deixá-los "para cima", também serve (e é utilizado aqui) como analogia a um estado de espírito de felicidade e disposição: estar "para cima" no sentido de bem-humorada e animada.

3. Os comerciais da linha primavera-verão das Lojas Marisa do ano de 2012 foram fortemente criticados por diferentes grupos feministas, sendo que alguns chegaram a organizar protestos em lojas da rede. Disponível em: <https://noticias.terra.com.br/brasil/garotas-do-femen-quebram-lojamarisa-em-bh-contra-comercial,da48af97a555b310VgnCLD200000bbcceb0aRCRD.html>. Acessado em 2 out. 2016.

Já a campanha de Dia dos Namorados de 2014 da marca O Boticário, ao valer-se de imagens e vídeos de "histórias reais" pelos internautas, foi criticada por LGBTs por, em sua montagem, dar visibilidade apenas a casais heterossexuais. A crítica aparentemente foi bem recebida e a campanha da mesma marca no Dia dos Namorados do ano seguinte foi bastante comentada, justamente por sugerir imagens de uniões homoafetivas. 
e Safernet, 2015) ${ }^{4}$ e No te mueras por mi (ONG.Viva Mujer - Peru, 2015). ${ }^{5}$

De todo modo, nota-se que as características específicas das mídias digitais e do atual contexto de sua distribuição propiciam uma relação diferenciada com as imagens publicitárias, marcada pela participação, formação de opinião e feedback imediato dos usuários de internet, sejam estes consumidores ou não dos produtos anunciados.

Hoje em dia, as possibilidades de manipulação e compartilhamento de imagens por qualquer usuário da internet permitem que sua difusão, muitas vezes, ocorra de forma diversa da planejada por seus produtores. Muitas campanhas, eventualmente, tornam-se conhecidas apenas em função de alguma polêmica que tenham promovido, sendo compartilhadas em anexo a textos que visam criticá-las e expor posicionamentos de reprovação. De maneira que o número de visualizações, comentários e compartilhamentos de um vídeo nas redes sociais, em si, não indica necessariamente uma campanha publicitária "bem-sucedida".

Em todo caso, vê-se aqui um aspecto interativo na relação com as imagens publicitárias, no que a publicação, nas redes sociais, de opiniões, comentários e críticas (e, às vezes, até de paródias) aponta para uma relação bem mais complexa e multifacetada de construção de imagens e identidades, que não necessariamente recusa ou abstém-se dos veículos de comunicação de massa ou do uso de imagens e narrativas conhecidas a partir desses veículos.

\section{Feminilidade e emoções no discurso de jovens mulheres}

Nas entrevistas abertas, foi notável uma ambivalência instigante nos discursos das jovens entrevistadas: ao mesmo tempo que, para várias delas, as redes sociais constituem um espaço de publicização de opiniões, sentimentos e gostos, elas também revelam preocupação quanto a "expor-se demais", mesmo nos casos em que a entrevistada destacava usar a rede apenas para comunicação com pessoas próximas e íntimas. Assim, em muitos casos, o Facebook, que aparecia no discurso como algo usado estritamente para fins de relações pessoais, também suscitava preocupações e ressalvas com o nível de exposição da vida pessoal que a rede supostamente promoveria.

Todas as 10 entrevistadas se declararam heterossexuais e graduandas do ensino superior. Destas, apenas 2 declararam possuir renda familiar superior a $\mathrm{R} \$$ 3.000,00. Em relação ao perfil étnico-racial, 4 se declararam brancas; 2, pardas; 2, negras; e 2 não responderam à questão. A maioria (6 entrevistadas) declarou estar solteira, enquanto as outras 4 afirmaram estar em um relacionamento sério. ${ }^{6}$ Chamou-nos a atenção também que, embora esta não fosse uma questão prevista no roteiro, 4 entrevistadas declararam espontaneamente que sua geração era a primeira na família a cursar o ensino superior.

Todas as entrevistadas concordaram com a ideia de que, nas redes sociais, as pessoas possuem uma imagem diferente daquela que corresponderia à sua personalidade "real"; ao mesmo tempo, algumas manifestaram a vontade de transmitir uma "imagem verdadeira de si mesmas". Palavras de Rosa, ${ }^{7}$ ao descrever a imagem que gostaria que tivessem dela nas redes sociais:

Uma pessoa assim, simplesmente normal, não aquela pessoa que tá no Facebook e "Oh, aconteceu um problema pessoal. Vou lá compartilhar pra todo mundo". Tem mais mendigo que uma pessoa carente [...] ou uma pessoa depressiva qualquer coisa assim não? Mas na verdade ela é uma pessoa que compartilha o que acha interessante, bacana, algo produtivo...

Em seu uso das redes sociais, as entrevistadas demonstraram particular preocupação em evitar demasiada exposição da vida privada, no sentido de compartilhar conteúdos de caráter "informativo", político ou religioso, que poderiam indicar crenças e convicções pessoais, mas resguardando a vida pessoal. A maioria das entrevistadas também afirmou desaprovar o compartilhamento, nas redes sociais, de declarações públicas de afeto, embora algumas, como Orquídea, não seguissem essa tendência: "Eu acho bonito pra pessoa, mas não pra mim. Eu acho fofo, mas no meu caso, eu não gosto muito dessas coisas não, carinho no Facebook".

4. Esta também despertou inúmeras críticas nas redes sociais, especialmente pela infeliz analogia "vazamento de intimidade", referindo-se tanto ao vazamento de imagens íntimas de mulheres na internet quanto ao vazamento do sangue menstrual. As críticas envolveram vários aspectos, como o uso "objetificado" da imagem da apresentadora Sabrina Satto, mas se concentraram na sugestão, implícita à campanha, de responsabilização das vítimas desses vazamentos, com menos ênfase no fato de que tal prática de compartilhamento de imagens é considerada crime.

5. Campanha de prevenção à violência contra a mulher em relacionamentos afetivos.

6. É digno de nota que todas as que se declararam pardas ou pretas também se declararam solteiras, o que sugere proximidade com o observado em estudos que apontam a dificuldade das mulheres negras de se casar ou conseguir um parceiro estável (Telles, 2003; Haraway, 2004; Souza, 2008).

7. Visando preservar a identidade e a privacidade das entrevistadas, os nomes utilizados são todos fictícios. 
Já a entrevistada Margarida ressaltou o caráter pessoal da rede social, tanto para seu uso quanto em sua percepção do uso de outras pessoas. O que, segundo ela, tornaria "normal" o compartilhamento, na rede, de declarações de afeto e fotos de casais, embora tenha se mostrado particularmente desfavorável a isso. Curiosamente, essa entrevistada, ao contrário de outras que não deram muita atenção à questão, julgou de grande importância o compartilhamento, na rede social, do status de relacionamento para aquelas em um "relacionamento sério".

"No meu ponto de vista, se a pessoa não atualiza o status dela, ela não tá afirmando um compromisso, não que o Facebook oficialize, mas atualmente ele tem essa força de impressão", afirma Margarida. Destaca-se aqui a "força da impressão" que a entrevistada atribui à rede, ainda que, em sua perspectiva, trate-se de uma rede bastante "pessoal". Desse modo, pode-se imaginar que, em tese, aqueles que vissem seu status de relacionamento já saberiam, por outros meios, da existência do compromisso.

Nesse sentido, é significativo o aspecto de uma construção e exposição reflexiva da imagem pessoal nas redes sociais, no sentido reiterativo, independente de interações face a face. Aqui, permanece como elemento fundamental a manutenção da "fachada pessoal" nos termos de Goffman (2005, p. 31), como "itens de equipamento expressivo [...] que de modo mais íntimo identificamos com o próprio ator e que naturalmente esperamos que o sigam onde quer que vá”.

Sobre percepções de feminilidade e afetividade, chamou a atenção que a maioria das entrevistadas, quando questionadas se consideravam-se pouco ou muito femininas, respondiam com base em sua relação com cuidados com o corpo e vaidade, independente de se afirmarem pouco ou muito femininas:

Acho que pra mim ser feminina eu não preciso necessariamente ficar "oh coisa fofa, gut gut", não, isso é frescura, eu gosto de vestir da forma que eu concebo que uma mulher deve se vestir. (Violeta).

Por um lado pela questão da feminilidade, tem a questão dos cuidados físicos, do lado emocional. (Margarida).

Eu me considero muito feminina. Eu gosto de me arrumar, de me maquiar, eu gosto muito de mudança, não gosto de nada igual [...] tipo mudar cabelo... (Orquídea).

Foi surpreendente a ênfase da maioria das entrevistadas na identificação entre feminilidade e cui- dados com a aparência, superando a expectativa de relatos mais espontâneos sobre a identificação das mulheres com a emotividade e a afetividade. Isso reforça as impressões apresentadas no tópico anterior, na análise de conteúdo dos vídeos. Contudo, não deixaram de aparecer, pulverizadas em diferentes trechos da entrevista, as associações entre feminilidade, emoções, maternidade e interesse em se casar, ainda que este último tópico não tenha se manifestado como prioritário.

Quando questionada sobre a importância do amor para a vida de uma mulher, a entrevistada Rosa afirmou: "Olha [...] eu acho que a mulher já nasce com isso, pelo fato dela poder gerar uma vida, eu acho que ela já sente mais amor, já vê amor em tudo." Mas, até o momento, a fala mais expressiva em relação à feminilidade e às emoções foi a de Margarida:

Feminilidade é, entra a vaidade, né, cuidado com a aparência, entra também o lado emocional, que também tá ligado a toda uma forma de criação que é imposto, né. Por exemplo, se eu tenho uma filha que é menina e ela cai e começa a chorar, automaticamente eu vou lá, pego ela e dou todo aquele carinho e atenção. Agora se for um menino, não no meu caso mas geralmente acontece, ocorre de muitas vezes repreender, "ah, você não vai chorar porque você é homem”. Então isso acarreta uma questão emocional, a mulher vai crescer com liberdade de expressar os sentimentos dela, principalmente esse lado mais questão de chorar mesmo, e o homem já não tem tanto isso, é mais fechado, trancado.

Interessante que ela expresse a relação das mulheres com as emoções como uma espécie de privilégio, na qualidade de uma "liberdade de expressar os sentimentos" que, na sua perspectiva, o homem não possuiria. Isso reforça uma percepção naturalizada da emotividade para o feminino, bem como reitera o gênero como elemento legitimador de experiência e expressão de emoções.

Também apareceram, em algumas falas, conflitos entre um ideal de amor "para sempre", representado pelo casamento, bem como a insegurança ou desconfiança em relação à possibilidade de manutenção duradoura desta relação. Se, por um lado, a visão pessimista de "amor líquido" (Bauman, 2004) pareça muito presente, no sentido de estimular uma descrença nos ideais amorosos e no casamento, o que se nota na fala de algumas entrevistadas é que o ideal e seus referenciais permanecem firmes, como que sagrados e desejáveis, mas, na perspectiva de algumas das entrevistadas, são vistos como algo que dependeria de supostas "competências" que perceberiam ausentes em si, como é o caso de Tulipa. 
Quando questionada se concordava com a afirmação de que toda mulher sonha em se casar, ela respondeu negativamente, justificando que não deseja se casar por não querer ter filhos e não se ver como mãe. Mas, ao desenvolver espontaneamente sua resposta, a entrevistada emocionou-se, expressando que não se vê como mãe e afirmou entre lágrimas:

Eu queria muito acreditar que as pessoas podem ficar juntas, mas acaba, sabe [...] Eu vejo que as pessoas não ficam juntas. Então eu não acredito, "ah, tem que casar, ah tem que ter filho." E eu não tenho jeito com criança. Eu não tenho jeito nenhum. Eu não sei como se aprende a ser mãe [...] então eu vejo assim que ultimamente [...] que o amor tá muito descartável. O que é o amor? Acho que eu nunca senti na minha vida. Eu sei o que é gostar muito de alguém. Eu sei o que é sonhar com uma pessoa, mas não sei se é amor, se as pessoas precisam selar um contrato pra dizer assim "agora a gente tá junto e nunca mais se separa". Isso é muito arriscado.

O conteúdo de sua fala, reforçado pela comoção, aponta o que, ao olhar mais desatento, sugere um paradoxo nas perspectivas de amor contemporâneas e suas relações com a feminilidade: a entrevistada não demonstra, por si, desacreditar o ideal do casamento "para sempre" e com fins reprodutivos. Seu discurso, por um lado, é pragmático, no sentido de não perceber a possibilidade de relações duradouras hoje, e, por outro lado, expressa uma forte autocensura: sua recusa pelo casamento, a princípio afirmada por não desejar ser mãe, logo é convertida numa expressão de descrença em relação às suas capacidades afetivas - "não tenho jeito com criança, não tenho jeito nenhum".

Em adição, permanece a centralidade atribuída ao amor para um relacionamento feliz, mas a insegurança sobre "o que seria o amor" gera um entrave, no sentido de contrair um vínculo que, supostamente, deveria ser fundamentado pela existência desse sentimento aparentemente distante, idealizado e, por isso mesmo, desconhecido. Assim, curiosamente, o amor em si, na perspectiva dessa entrevistada - e em expressões e textos compartilhados por muitos jovens nas redes sociais, hoje -, não se revela descartável ou "vulgarizado" como muitos tendem a declarar, apoiando-se em suas leituras de Bauman. Mas, ao contrário, tem suas características de distinção e méritos especiais exacerbadas.

Dessa forma, entende-se que mudanças nas formas de perceber e experimentar as relações amorosas na contemporaneidade, do ponto de vista valorativo, mantêm-se tímidas. Os ideais de amor verdadeiro, à exemplo da tradição romântica, parecem cada vez mais inatingíveis, ficcionais, uma vez que ainda pautados por - entre outros elementos - uma perenidade transcendental de sentimentos agradáveis no tempo e no espaço que parece cada vez mais incoerente com a velocidade dos fluxos de trocas de experiências, informações e interações na atualidade. É justamente esse caráter aparentemente inatingível atribuído ao amor romântico que, historicamente, está no cerne de seu enobrecimento.

Dessa forma, aparentemente, os ideais de amor aprendidos e reproduzidos por essas jovens mulheres parecem cada vez menos corresponder às suas vivências práticas e demandas cotidianas, o que, em se tratando de amor romântico, não seria novidade. O problema é a crença nesse modelo como o único válido, viável e desejável. Conforme aponta Serge Chaumier (1999, p. 210):

Os modelos antigos não convêm mais, mas continuamos a tomá-los como referências, estando os novos padrões emergentes ainda largamente inconscientes. É necessário, sobretudo, insistir na importância das representações sociais da arte de amar que continuam a assegurar principalmente uma socialização seguindo o modelo antigo, ainda que as práticas sociais tenham mudado.

Considerando a fala citada de Tulipa em conjunto com demais trechos de sua entrevista, ela parece, de diferentes formas, expressar uma forte autocensura quanto a seus sentimentos e relacionamentos, no sentido de até verbalizar em outro momento que "deveria ser mais romântica". O aspecto das normas emocionais (Thoits, 1991) se manifesta aqui de forma marcante, no que se refere a prescrições de um "dever ser" em relação aos sentimentos.

Nota-se que a entrevistada preserva ideais românticos tradicionais como um norte de conduta e de avaliação de suas relações e sentimentos, embora os julgue, para si, inalcançáveis. Mais do que criticar esses ideais ou a instituição do casamento, sua fala direciona a crítica a si mesma. A dificuldade da entrevistada não é percebida como efeito de fenômenos sociais, mas como problema de competência pessoal.

Nota-se, então, uma significativa dualidade, na qual pressões sociais são internalizadas e reinterpretadas como dados pessoais, de maneira a remeter a Bourdieu (1972, p. 13) ${ }^{8}$ ao propor uma "dialética da interioridade e da exterioridade, isto é, da interiorização da exterioridade e da exteriorização da interioridade". Convém observar, entretanto, que, no caso do debate de gêneros, os aspectos socialmente estruturados facilmente se confundem e se reafirmam como determinações biológicas e naturais, contri- 
buindo para a manutenção de crenças a respeito de propriedades e competências emocionais "naturais de um sexo ou outro".

Tanto na experiência das emoções quanto na do desejo sexual e da afetividade, há elementos que, no discurso comum, estabelecem esses temas como restritos à "interioridade", contribuindo para que não sejam problematizados em seus aspectos relacionais ao tecido social. Assim, certamente, muitas mulheres, a exemplo dessa entrevistada, significariam suas vivências amorosas exclusivamente do ponto de vista de sua suposta e autêntica internalidade, excluindo do processo as pressões sociais e culturais - da expectativa de familiares a modelos de felicidade conjugal midiaticamente difundidos - nas quais essas vivências ocorrem.

A presença marcada dessas perspectivas não significa, na percepção das entrevistadas, um consenso sobre a maternidade enquanto aspecto de competência individual. Iris expressara uma visão a princípio diversa, mas que talvez traduza o desconforto expresso por Tulipa em termos das expectativas projetadas sobre as mulheres em relação à maternidade:

eu acho que a sociedade estranha isto, uma mulher não querer ser mãe, vão dizer: "ah, isso é só agora que está falando, mas quando você se apaixonar e casar o seu sonho vai ser mãe", mas talvez não, talvez a pessoa não queira realmente ser mãe, eu acho que é escolha mesmo da pessoa, cada um tem a sua vida e faz o que quer, só que eu acho que com certeza sim tem pessoas que tem vergonha de dizer isso, porque a sociedade vê mulher como sendo mãe algum dia, casando e sendo mãe.

Deste modo, é interessante observar que, embora todas as entrevistadas atribuam especial importância à conquista de sua independência financeira e de seu sucesso profissional, isso não necessariamente as afastou de pressões e crenças a respeito da feminilidade direcionadas ao casamento e à maternidade. Convém notar, também, que o fato de todas estarem matriculadas em cursos superiores certamente impacta em sua valorização de conquistas profissionais.

Pode-se dizer que algumas das entrevistadas encontram-se em posição de potencial mobilidade social em relação a seus genitores, em função do acesso à educação superior, o que afetaria significativamente seus planos de vida e o papel de um relacionamento amoroso nesses planos. Mesmo aquelas que se mostraram mais inclinadas ao casamento e à maternidade, valorizando a importância do amor para a vida de uma mulher, enfatizaram o desejo de primeiro concluir seus cursos de graduação e conquistar estabilidade e independência financeira, para depois constituir família. De maneira que o casamento e a maternida- de ainda se mantêm como destinos importantes para suas vidas, mas sob condições específicas que contemplem sua independência profissional e financeira.

\section{Considerações finais}

Buscou-se, neste artigo, lançar luz sobre dois campos relevantes e ainda pouco explorados sociologicamente: o uso de mídias digitais na contemporaneidade, do ponto de vista de sua incorporação às sociabilidades cotidianas e na construção de identidades, e o campo das emoções como algo social e historicamente constituído - algo demarcado e, ao mesmo tempo, demarcador de diferenças sociais, hierarquias e relações de poder, no que se inclui a produção de gêneros. O aparente impulso a compartilhar "tudo o que se sente" nas redes sociais, a respeito de política, relacionamentos e todos os assuntos possíveis, parece-nos profícuo e ainda pouco explorado, seja pela sociologia, de forma geral, ou pela sociologia das emoções.

Considerando que já há uma geração de nativos digitais (Prensky, 2001) chegando na idade adulta, entrando no mercado de trabalho e iniciando (ou preparando-se para) uma vida conjugal, é importante compreender como suas performances e percepções mesmo em relação a gêneros e à sexualidade - são constituídas, questionadas e reflexivamente reformuladas também a partir do uso cotidiano dessas mídias em suas relações íntimas e sociais. Novos códigos de relacionamentos são estabelecidos, bem como formas mais ou menos desejáveis de expressar emoções - não somente na intimidade, mas socialmente -, do que a publicação do status de relacionamento nas redes sociais é apenas um exemplo.

Uma série de normas sociais específicas permeia as relações mediadas pelas novas tecnologias de comunicação, e também nelas há limites, interditos, prescrições e modos considerados legítimos e desejáveis de expressão de gostos e afetos. E todos esses, mais ou menos diretamente, passam pelo escrutínio de demarcações de gênero e expressam a manutenção de relações gendradas de poder. O exemplo mais patente seria o dos casos de pornografia de vingança, como forma de abuso majoritariamente exercido por homens sobre mulheres.

$\mathrm{Na}$ maioria dos casos conhecidos, os atores desse tipo de violência simbólica são ex-parceiros de algum relacionamento duradouro. O escrutínio diferenciado por gênero é perceptível no momento em que essas imagens íntimas, uma vez difundidas, são julgadas por internautas, no sentido de culpabilizar as vítimas e censurá-las por permitirem ser filmadas e/ou fotografadas, por seus parceiros íntimos, em performances 
eróticas. Não bastasse o constrangimento sofrido por essas mulheres, ainda há parcelas significativas da população ocupadas em censurar seu comportamento sexual e afetivo.

Pôde-se notar, também, que alguns questionamentos simples lançados às entrevistadas, - relativos a suas percepções de relacionamentos afetivos, sonhos e crenças amorosas - revelaram-se desafiadores como questões que, aparentemente, elas não se colocariam espontaneamente, levando-as a refletir sobre sua condição como mulheres, bem como seus desafios, expectativas, ideais e decepções.

Entende-se que afirmações e crenças amplamente reproduzidas - de que as mulheres seriam naturalmente mais emotivas, afetivas e predispostas à maternidade e ao contrato matrimonial - mereçam ser estudadas e confrontadas mais incisiva e sistematicamente pela sociologia, considerando a visibilidade ainda limitada desses temas na academia como uma forma de deslegitimar um elemento crucial nas formas com que gêneros são socialmente significados e incorporados em orientações de modos de pensar e agir, bem como de interpretar valorativamente e estimular ou rechaçar emoções.

Estima-se com este texto, por fim, estimular mais reflexões e debates, do ponto de vista sociológico, sobre gêneros, emoções e impactos de novas mídias na vida cotidiana e na constituição destas duas importantes categorias que balizam ações, reações e relações, tanto pessoais quanto sociais.

\section{Referências}

BAUMAN, Zygmunt. Amor líquido: sobre a fragilidade dos laços humanos. Rio de Janeiro: Jorge Zahar, 2004.

BELELI, I. Corpo e identidade na propaganda. Estudos Feministas, Florianópolis, v. 15, n. 1, p. 280, jan.-abr. 2007. BIDAUD, Anne-Marie. Hollywood et le rêve américain. Paris: Masson, 1994.

BOURDIEU, Pierre. Esboço de uma teoria da prática.Trad. de Paula Montero. 1972. Disponível em: https://disciplinas. stoa.usp.br/pluginfile.php/352755/mod_resource/ content/1/Esbo\%C3\%A7o\%20de\%20uma\%20teoria\%20 da\%20pr\%C3\%A1tica.pdf. Acesso em: 2 set. 2016.

BUTLER, Judith. Corpos que pesam. In: LOURO, Guacira Lopes (Org.) O corpo educado. Belo Horizonte: Autêntica, 2000. BUTLER, Judith. Problemas de gênero. Rio de Janeiro: Civilização Brasileira, 2013.

CHAUMIER, Serge. La déliaison amoureuse. Paris: Armand Colin, 1999

CASTELLS, Manuel. Sociedades em rede. São Paulo: Paz e Terra, 2005. (v. 1).

FOUCAULT, Michel. História da sexualidade: a vontade de saber. Rio de Janeiro: Graal, 2009. (v. 1).
GOFFMAN, Erving. Gender Advertisement. New York: Harper \& Row, 1987.

GOFFMAN, Erving. A representação do Eu na vida cotidiana. Petrópolis: Vozes, 2005.

HARAWAY, Donna. "Gênero" para um dicionário marxista. Cadernos Pagu, Unicamp, Campinas, n. 22, p. 201-246, jan.jun. 2004.

ILLOUZ, Eva. O amor nos tempos do capitalismo. Rio de Janeiro: Zahar, 2011.

LOURO, Guacira Lopes. Pedagogias da sexualidade. In: LOURO, Guacira Lopes (Org.). O corpo educado. Belo Horizonte: Autêntica, 2000.

MARTINS, José de Souza. Sociologia da fotografia e da imagem. São Paulo: Contexto, 2008.

MCQUIRE, Scott. The media city. London: SAGE Publications, 2008.

MISKOLCI, Richard. Novas conexões: notas teórico-metodológicas. Cronos, UFRN, Natal, v. 12, n. 2, p. 9-22, jul.-dez. 2011.

PRENSKY, M. Digital natives digital immigrants. In: PRENSKY, Marc. On the Horizon. NCB University Press, v. 9, n. 5, out. 2001. Disponível em: http://marcprensky. com/articles-in-publications/. Acesso em: 4 fev. 2016.

SCOTT, Joan. Gênero: uma categoria útil de análise histórica. Educação e Realidade, Porto Alegre, v. 15, n. 2, jul.-dez. 1990.

SHIELDS, Stephanie A. Speaking from the heart: gender and the social meaning of emotion. Cambridge: University Press, 2002.

SORLIN, Pierre.Sociologie du cinéma. Paris: Aubier Montaigne, 1982.

SOUZA, Claudete Alves da Silva. A solidão da mulher negra: sua subjetividade e seu preterimento pelo homem negro na cidade de São Paulo. 2008. 174 f. Dissertação (Mestrado em Ciências Sociais) - Pontifícia Universidade Católica de São Paulo, São Paulo, 2008.

STOLKE, Verena. La mujer es puro cuento: la cultura del género. Estudos Feministas, v. 12, n. 2, maio-ago. 2004.

TELLES, Edward. Racismo à brasileira: uma nova perspectiva sociológica. Rio de Janeiro: Relume-Dumará, 2003.

THOITS, Peggy. Emotional Deviance. In: KEMPER, T. D. (Org.). Research Agendas in the Sociology of Emotions. Albany: State University of New York Press, 1991.

WEBER, Max. A “objetividade" do conhecimento nas ciências e na política sociais. In: Ensaios sobre a teoria das ciências sociais. São Paulo: Centauro, 2008.

\section{VÍDEOS CITADOS}

\#JuntasContraVazamentos. Always Brasil. Disponível em: https://www.youtube.com/watch? $v=$ pkW3M3dmGvY. Publicado em 24 mar. 2015. Acesso em: 13 set. 2015.

Dia dos Namorados - O Boticário. O Boticário. Disponível em: https://www.youtube.com/watch? $\mathrm{v}=\mathrm{p} 4 \mathrm{~b} 8$ BMnolDI. Publicado em 25 maio 2015. Acesso em: 13 set. 2015.

Histórias reais do Primeiro Encontro. Samsung Brasil. Disponí- 
vel em: https://www.youtube.com/watch? $\mathrm{v}=\mathrm{xf} 4 \mathrm{o} 1 \mathrm{j}$ Vnyio. Publicado em 29 jul. 2014. Acesso em: 13 set. 2015.

Homenagem surpresa no cinema. Natura Brasil. Disponível em: https://www.youtube.com/watch?v=xjICQywTMQ4. Publicado em 27 out. 2011. Acesso em: 13 set. 2015.

O Boticário - Homenagem dia dos namorados. O Boticário. Disponível em: https://www.youtube.com/ watch? $\mathrm{v}=\mathrm{PLVz3oVzXxE}$. Publicado em 25 maio 2014. Acesso em: 13 set. 2015.

Toda mulher merece um elogio. Lojas Villa, Scala, Carmen Steffens - São Luís, MA. Disponível em: https://www. youtube.com/watch? $v=$ GYyxcijttrY. Publicado em 7 mar. 2013. Acesso em: 13 set. 2015. 


\title{
The feminine in digital media: uses of images and social networks in constructing emotional references of gender
}

\begin{abstract}
This paper argues how femininity images are socially constituted, shared and reproduced in social networks and digital media by users as much as in advertisements focused on young women in nowadays. The paper consists on analyzing ten advertisement videos shared in social networks and available on Youtube, combining a content analysis on ten semi structured interviews with women between 18 and 25 years old, users of Facebook. It was observed the maintenance of values and beliefs referring to intimate and affective life, whereas persist - even though re-signified - heteronormative and monogamist ideals of affective union. As such, marriage and maternity still play an important role in constituting life plans for women. In this way, under new mechanisms of reproduction and interpretation, persists a romantic idealization on love relationships, as well of a "female nature" marked by the inclination to affectivity.
\end{abstract}

Keywords: gender; femininity; digital media; images; sociology of emotions.

\section{El femenino en los medios digitales: usos de imágenes $y$ redes sociales em la construcción de referencias emocionales de género}

\section{Resumen}

Este artículo discute cómo imágenes de la feminidad se constituyen socialmente hoy, compartidas y reproducidas en redes sociales y en los medios digitales, tanto por las propias usuarias como en campañas de publicidad dirigidas al público femenino joven. El artículo consiste en el análisis de diez vídeos publicitarios compartidos en redes sociales y disponibles en el canal de vídeos YouTube, combinado con el análisis de contenido de las entrevistas semi-estructuradas con diez mujeres de entre 18 y 25 años y los usuarias de la red social Facebook. Se observó el mantenimiento de las creencias y valores referentes a la vida íntima y afectiva, en el que persisten, aunque con nuevos significados, ideales héteronormativos y monogámicos de unión afectiva, donde el matrimonio y la maternidad siguen como elementos significativos en la constitución de proyectos de vida femeninos. En esto persistiría, bajo nuevos mecanismos de reproducción e interpretación, una idealización romántica de relaciones amorosas y de una "naturaleza femenina" marcada por la inclinación a la afectividad.

Palabras clave: género, feminidad, medios de comunicación digitales, imágenes, sociología de las emociones.

Data de recebimento do artigo: 02/11/2016 Data de aprovação do artigo: 01/04/2017 
